\title{
The chlorobenzoate dioxygenase genes of Burkholderia sp. strain NK8 involved in the catabolism of chlorobenzoates
}

\author{
Perigio B. Francisco Jr, Naoto Ogawa, Katsuhisa Suzuki \\ and Kiyotaka Miyashita
}

Author for correspondence: Kiyotaka Miyashita. Tel: +8129838 8256. Fax: +8129838 8199. e-mail:kmiyas@s.affrc.go.jp

Soil General Microbiology Laboratory, National Institute of AgroEnvironmental Sciences, 3-1-1 Kannondai, Tsukuba City, Ibaraki 305-8604, Japan
Burkholderia sp. NK8 grows abundantly on 3-chlorobenzoate (3CB), 4-chlorobenzoate (4CB) and benzoate. The genes encoding the oxidation of (chloro)benzoates (cbeABCD) and catechol (catA, catBC), the LysR-type regulatory gene cbeR and the gene cbeE with unknown function, all of which form a single cluster in NK8, were cloned and analysed. The protein sequence of chlorobenzoate 1,2-dioxygenase (CbeABC) is 50-65\% identical to the benzoate dioxygenase (BenABC) of Acinetobacter sp. ADP1, toluate dioxygenase (XyIXYZ) of the TOL plasmid pWWO and 2-halobenzoate dioxygenase (CbdABC) of Burkholderia cepacia 2CBS. Disruption of the cbeA gene resulted in the simultaneous loss of the ability to grow on benzoate and monochlorobenzoates, indicating the involvement of the cbeABCD genes in the degradation of these aromatics. The cbeABCD genes are preceded by cat $A$, the gene for catechol dioxygenase. lac $Z$ transcriptional fusion studies in Pseudomonas putida showed that cat $A$ and cbe $A$ are co-expressed under the positive control of $c b e R$, a LysR-type transcriptional regulatory gene. The cbe $A$ : : lacZ transcriptional fusion studies showed that the inducers of the genes are $3 \mathrm{CB}, 4 \mathrm{CB}$, benzoate and probably cis,cis-muconate. On the other hand, 2-chlorobenzoate (2CB) did not activate the expression of the genes. The chlorobenzoate dioxygenase was able to transform 2CB, 3CB, 4CB and benzoate at considerable rates. $2 \mathrm{CB}$ yielded both catechol and 3-chlorocatechol (3CC), and 3 CB gave rise to 4-chlorocatechol and $3 C C$ as the major and minor intermediate products, respectively, indicating that the NK8 dioxygenase lacks absolute regiospecificity. The absence of growth of NK8 on 2CB, despite its considerable degradation activity against $2 \mathrm{CB}$, is apparently due to the inability of CbeR to recognize $2 \mathrm{CB}$ as an inducer of the expression of the cbe genes.

Keywords: Burkholderia, chlorobenzoate dioxygenase, cbeABC, cbeR, cat $A$

\section{INTRODUCTION}

Chlorobenzoates are the major intermediate products of aerobic catabolism of polychlorinated biphenyls (PCBs).

\footnotetext{
Abbreviations: $2 \mathrm{CB}$, 2-chlorobenzoate; $3 \mathrm{CB}$, 3-chlorobenzoate; $4 \mathrm{CB}, 4$ chlorobenzoate; 3CC, 3-chlorocatechol; 4CC, 4-chlorocatechol; BSMG basal synthetic medium + glucose; DA, Davis-adonitol medium; DHB, dihydrodihydroxybenzoate (3,5-cyclohexadiene-1,2-diol-1-carboxylic acid); PCBs, polychlorinated biphenyls.

The GenBank accession number for the sequence reported in this paper is AB024746.
}

In most PCB-degrading micro-organisms, however, chlorobenzoates are not further metabolized (Unterman, 1996). Degradation of chlorobenzoates, therefore, is important for the complete degradation of PCBs. Chlorobenzoate-degrading bacteria that possess aromatic-ring-hydroxylating dioxygenases involved in the initial steps of chlorobenzoate catabolism have been isolated from soil. Genes encoding these dioxygenases have been identified. These are the 3-chlorobenzoate 3,4-dioxygenase $(c b a A B)$ and dehydrogenase (cbaC) genes of Alcaligenes sp. BR60 (Nakatsu \& Wyndham, 1993; Nakatsu et al., 1995, 1997), the 2-halobenzoate 
1,2-dioxygenase genes (cbdABC) of Burkholderia cepacia 2CBS (Haak et al., 1995) and the orthohalobenzoate 1,2-dioxygenase genes $(o h b A B)$ of Pseudomonas aeruginosa 142 (Tsoi et al., 1999). CbaABC generates protocatechuate and 5 -chloroprotocatechuate from 3-chlorobenzoate (3CB), while $\mathrm{CbdABC}$ and OhbAB produce catechol from 2-chlorobenzoate (2CB) in the respective bacteria.

Bacterial degradation of chlorobenzoate via chlorocatechol is supposed to be one of the typical degradation pathways for chlorobenzoates. In this pathway, chlorobenzoates are converted to chlorocatechols by (chloro)benzoate dioxygenase and (chloro)benzoatedihydrodiol dehydrogenase (Focht, 1996), and the chlorocatechols thus generated are transformed by the so-called 'modified ortho pathway' enzymes (Harwood \& Parales, 1996; Reineke, 1998; van der Meer et al., 1992). The genes encoding these enzymes were apparently derived from the 'ortho pathway' genes for catechol degradation (Daubaras \& Chakrabarty, 1992; Frantz \& Chakrabarty, 1987; Reineke, 1998; van der Meer et al., 1992). While the structure and expression of the modified ortho pathway genes have been extensively studied (McFall et al., 1998; van der Meer et al., 1992), those genes for (chloro) benzoate dioxygenase in bacteria that transform chlorobenzoates to chlorocatechols have not been sufficiently examined. Analysis of (chloro)benzoate dioxygenase genes is essential for the elucidation of the molecular mechanism of chlorobenzoate degradation.

Burkholderia sp. NK8 is a soil isolate that shows broad specificity for chlorobenzoate degradation, being capable of growth on $3 \mathrm{CB}$ and 4-chlorobenzoate (4CB). The current study was conducted to examine the genes for chlorobenzoate dioxygenase(s) responsible for the broad substrate specificity of NK8 for chlorobenzoates. The chlorobenzoate dioxygenase genes of NK8 were cloned and analysed using various genetic and enzymic methods.

\section{METHODS}

Bacterial strains, plasmids and bacterial growth conditions. Bacterial strains and plasmids used in this study are listed in Table 1. Burkholderia sp. NK8, which was isolated in Japan from a $3 \mathrm{CB}$-enriched soil sample, has a $16 \mathrm{~S}$ rDNA sequence that is $97 \%$ and $95 \%$ identical to those of Burkholderia glathei (GenBank accession no. U96935) and Burkholderia andropogonis (accession no. X67037), respectively. The plasmids pUC118 and pBluescript II KS $(+)$ were routinely used as cloning vectors while Escherichia coli strains $\mathrm{DH} 5 \alpha$, S17-1 and S17-1 ipir were used as plasmid hosts. E. coli cells were grown on Luria-Bertani broth (LB) (Sambrook et al., 1989), Pseudomonas putida on LB or Pseudomonas isolation agar (Difco), while NK8 cells were cultured either on LB or on a basal salts medium (Ogawa \& Miyashita, 1995) supplemented with benzoate, $2 \mathrm{CB}, 3 \mathrm{CB}$ or $4 \mathrm{CB}$ at a final concentration of $5 \mathrm{mM}$. Selection for transconjugants of NK8 and its derivatives was done on Davis-adonitol (DA) medium [per litre: $7 \mathrm{~g} \mathrm{~K} \mathrm{~K}_{2} \mathrm{HPO}_{4}, 2 \mathrm{~g} \mathrm{KH}_{2} \mathrm{PO}_{4}, 1 \mathrm{~g}\left(\mathrm{NH}_{4}\right)_{2}\left(\mathrm{SO}_{4}\right)_{2}, 0 \cdot 1 \mathrm{~g}$ $\mathrm{MgSO}_{4} \cdot 7 \mathrm{H}_{2} \mathrm{O}, 2 \mathrm{~g}$ adonitol]. As needed, antibiotics were added at the following concentrations $\left(\mu \mathrm{g} \mathrm{ml} \mathrm{m}^{-1}\right)$ : ampicillin (for E. coli), 50; gentamicin, 20; hygromycin, 50; kanamycin, 50; chloramphenicol, 25; and carbenicillin (for P. putida), 1000. E. coli cells were grown at $37^{\circ} \mathrm{C}$ while Pseudomonas and Burkholderia strains were cultured at $30^{\circ} \mathrm{C}$.

DNA manipulation. Genomic DNAs were prepared as described by Ausubel et al. (1987) and plasmid DNA preparations were done using Qiagen spin mini- and midiprep kits (Qiagen). Restriction enzyme digestions and DNA ligations were performed following the recommendations of the suppliers (Takara, Toyobo and NipponGene). Competent cells for transformations by electroporation in a Bio-Rad Gene Pulser or by $42{ }^{\circ} \mathrm{C}$ heat shock were prepared using the methods of Smith et al. (1990) and Hanahan (1985), respectively. All DNAs for ligation (vectors and inserts) were purified from agarose gels using GeneClean II (Bio101). Mobilizations were performed basically as described by Franklin (1985).

Cloning of the benzoate dioxygenase genes. Degenerate PCR primers were designed from highly homologous regions of benA of Acinetobacter sp. strain ADP1 and $x y l X$ of $P$. putida TOL plasmid pWW0 (Harayama et al., 1991). Using purified NK8 genomic DNA as template, PCRs were carried out with different degenerate primer combinations. The forward primer BAf1 [5'-GC(C/T)CA(C/T)GA(G/A)AGCCAGATTCCC-3'] with the reverse primer BAr2 [5'-GGTGG$\left.\mathrm{C}(\mathrm{G} / \mathrm{T}) \mathrm{GC}(\mathrm{G} / \mathrm{A}) \mathrm{TAGTTCCAGTG}-3^{\prime}\right]$ yielded an approximately 500 bp fragment, which was then cloned in the pCR2.1 TA cloning vector (Invitrogen) and sequenced with an ALFred DNA Sequencer (Pharmacia Biotech). The cloned PCR product was used to probe for the benzoate dioxygenase genes of Burkholderia sp. NK8. Purified NK8 genomic DNA was digested with various restriction endonucleases. Restriction fragments were separated on an agarose gel by electrophoresis and then blotted onto Hybond-N+ nylon membrane (Amersham). The Southern blot was probed with the $500 \mathrm{bp}$ PCR product labelled using the DIG Nucleic Acid Detection Kit (Boehringer Mannheim). An approximately $5 \cdot 3 \mathrm{~kb}$ EcoRI fragment was selected for cloning into pUC118 and pBluescript II $\mathrm{KS}(+)$. DNA fragments of about $5-5.5 \mathrm{~kb}$ recovered from the agarose gel were cloned and used to transform E. coli DH5 $\alpha$. Identification of positive clones was done by colony hybridization with the DIG-labelled PCR product. Putative clones were verified through direct colony PCR with the primers BAf1 and BAr2, followed by Southern blot analysis. The $868 \mathrm{bp} E c o$ RI-Pst I segment at the left end of the cloned $5.3 \mathrm{~kb}$ EcoRI fragment in Fig. 1 was excised, labelled and used to probe NK8 genomic DNA for overlapping upstream fragments. Among the positive bands, the $8.1 \mathrm{~kb}$ HindIII-PstI fragment was selected for cloning into pBluescript II KS $(+)$.

Sequencing and sequence analysis. The restriction maps of the cloned NK8 DNA fragments were drawn for generating subclones for sequencing. Overlapping subcloned fragments were sequenced in an ABI 373S Automated Sequencer (PerkinElmer Applied Biosystems) with the ABI Dye Primer Ready Reaction Kit according to the manufacturer's instructions. Sequences were generated from both DNA strands. Ambiguous portions of any sequence were verified by resequencing with the ABI Dye Terminator Ready Reaction Kit. Nucleotide sequence data were analysed using the GENETYX-Mac (version 10.1) and ATSQ software (Software Development).

Determination of (chloro)benzoate dioxygenase activity. NK8 cells were grown on succinate, benzoate or 3CB liquid medium to late exponential phase, harvested by centri- 
Table 1. Bacterial strains and plasmids

$\mathrm{Ap}^{\mathrm{r}}$, ampicillin resistant; $\mathrm{Cm}^{\mathrm{r}}$, chloramphenicol resistant; $\mathrm{Gm}^{\mathrm{r}}$, gentamicin resistant $\mathrm{Hm}^{\mathrm{r}}$, hygromycin resistant; $\mathrm{Km}^{\mathrm{r}}$, kanamycin resistant; $\mathrm{Rp}^{\mathrm{r}}$, rifampicin resistant; $\mathrm{Sm}^{\mathrm{r}}$, streptomycin resistant; $\mathrm{Tc}^{\mathrm{r}}$, tetracycline resistant; $\Omega$, omega interposon.

\begin{tabular}{|c|c|c|}
\hline Strain/plasmid & Relevant properties & Source/reference \\
\hline \multicolumn{3}{|l|}{ Burkholderia sp. strains } \\
\hline NK8 & Benzoate $^{+}, 3 \mathrm{CB}^{+}, 4 \mathrm{CB}^{+}$ & This study \\
\hline NDBA1 & cbeA:: $\Omega \mathrm{Gm}^{\mathrm{r}}$, megaplasmid ${ }^{-}$ & This study \\
\hline NCAD & $\operatorname{cat} A:: \Omega \mathrm{Gm}^{\mathrm{r}}$ & This study \\
\hline NCRD & cbeR:: $\Omega \mathrm{Hm}^{\mathrm{r}}$ & This study \\
\hline NBALZ & cbeA::lacZ-Km ${ }^{\mathrm{r}}$ & This study \\
\hline \multicolumn{3}{|l|}{ P. putida strains } \\
\hline PRS4020 & cbeR:: $\Omega \mathrm{Gm}^{\mathrm{r}}$, benzoate ${ }^{-}$ & $\begin{array}{l}\text { Parales \& Harwood } \\
\quad(1993)\end{array}$ \\
\hline \multicolumn{3}{|l|}{ E. coli strains } \\
\hline $\mathrm{DH} 5 \alpha$ & $\begin{array}{l}\text { supE44 lacU169(f80lacZ } \varphi \mathrm{M} 15) \text { hsdR17 recA1 } \\
\text { endA1 gyrA96 thi-1 relA1 }\end{array}$ & Gibco BRL \\
\hline S17-1 & $\begin{array}{l}\mathrm{C} 600:: \mathrm{RP} 42-(\mathrm{Tc}:: \mathrm{Mu})(\mathrm{Km}:: \mathrm{Tn} 7) \text { thi pro } \\
h s d R \text { hsd } \mathrm{M}^{+} \text {recA }\end{array}$ & Simon et al. (1983) \\
\hline S17-1 ipir & $\mathrm{K}-12, \mathrm{Sm}^{\mathrm{r}}$ & $\begin{array}{l}\text { de Lorenzo \& Timmis } \\
\text { (1994) }\end{array}$ \\
\hline HMS174(DE3) & K-12 expression host, $\mathrm{Rp}^{\mathrm{r}}(\mathrm{E} 3)$ & Novagen \\
\hline \multicolumn{3}{|l|}{ Plasmids } \\
\hline pUC118 & $\mathrm{Ap}^{\mathrm{r}}$; cloning vector & $\begin{array}{l}\text { Vieira \& Messing } \\
(1987)\end{array}$ \\
\hline pBlueScript II KS $(+)$ & $\mathrm{Ap}^{\mathrm{r}}$; cloning vector & Stratagene \\
\hline pCR2.1 & TA cloning vector & Invitrogen \\
\hline $\mathrm{pHP} 45 \Omega a a c$ & $\mathrm{Ap}^{\mathrm{r}}$; source of $\Omega \mathrm{Gm}^{\mathrm{r}}$ cassette & $\begin{array}{l}\text { Blondelet-Rouault } \\
\text { et al. (1997) }\end{array}$ \\
\hline $\mathrm{pHP} 45 \Omega h y g$ & $\mathrm{Hm}^{\mathrm{r}}$; source of $\Omega \mathrm{Hm}^{\mathrm{r}}$ cassette & $\begin{array}{l}\text { Blondelet-Rouault } \\
\text { et al. (1997) }\end{array}$ \\
\hline pNOT 322 & $A p^{r} T c^{r} ;$ cloning vector & Schweizer (1992) \\
\hline pMOB3 & $\mathrm{Km}^{\mathrm{r}} \mathrm{Cm}^{\mathrm{r}}$; source of $\mathrm{MOB}$ cassette & Schweizer (1992) \\
\hline pJRD215 & $\mathrm{Sm}^{\mathrm{r}} \mathrm{Km}^{\mathrm{r}} ;$ cosmid vector & Davison et al. (1987) \\
\hline pBAC1 & NK8 cat-cbe genes in pJRD215 & This study \\
\hline pET14b & Expression vector & Novagen \\
\hline p14BEP & cbe $A B C D$ in $\mathrm{pET} 14 \mathrm{~b}$ & This study \\
\hline pKOK6.1 & $\begin{array}{l}\text { Derivative of pKOK6 (Kokotek \& Lotz, 1989), } \\
\text { source of lacZ-Kmr cassette }\end{array}$ & W. Lotz* \\
\hline pQF50 & lacZ promoter probe vector, $\mathrm{Ap}^{\mathrm{r}}$ & $\begin{array}{l}\text { Farinha \& Kropinski } \\
\text { (1990) }\end{array}$ \\
\hline pFJ50cbeRcatAcbeA' & $\begin{array}{l}2.8 \mathrm{~kb} \text { EcoRV cbeRcatAcbe } A^{\prime} \text { insert in pQF50, } \\
\text { cbeA truncated at aa } 35 \text { out of } 452\end{array}$ & This study \\
\hline $\begin{array}{l}\text { pFJ50cbeRcatA : : } \Omega \mathrm{Hm}^{\mathrm{r}} \\
\text { cbeA }\end{array}$ & $\begin{array}{l}5 \cdot 1 \mathrm{~kb} \text { EcoRV cbeRcat } A:: \Omega h y g \mathrm{cbeA}^{\prime} \text { insert in } \\
\text { pQF50, cbeA truncated at aa } 35 \text { out of } 452\end{array}$ & This study \\
\hline pFJ50cbeR'catAcbeA' & $\begin{array}{l}1 \cdot 7 \mathrm{~kb} \text { Sall-EcoRV cbeR'catA-cbe } A^{\prime} \text { insert in } \\
\text { pQF50, cbeA truncated at aa } 35 \text { out of } 452 \text {, } \\
\text { cbeR truncated at aa } 128 \text { out of } 306\end{array}$ & This study \\
\hline pFJ50cbeRcatA' & $\begin{array}{l}1.9 \mathrm{~kb} \text { EcoRV-StuI cbeRcat } A^{\prime} \text { insert in pQF50, } \\
\text { catA truncated at aa } 77 \text { out of } 311\end{array}$ & This study \\
\hline pFJ50cbeR'catA' & $\begin{array}{l}790 \text { bp SalI-StuI cbeR'cat } A^{\prime} \text { insert in pQF50, } \\
\text { cat A truncated at aa } 77 \text { out of } 311, c b e R \\
\text { truncated at aa } 128 \text { out of } 306\end{array}$ & This study \\
\hline
\end{tabular}

*Friedrich-Alexander Universität, Erlangen, Germany. 
fugation, washed three times with $20 \mathrm{mM}$ potassium phosphate buffer $(\mathrm{pH} 7 \cdot 5)$ and stored at $-80{ }^{\circ} \mathrm{C}$ until used. The cells were thawed on ice, disrupted by sonication and ultracentrifuged at $164000 \mathrm{~g}$ for $40 \mathrm{~min}$ at $4{ }^{\circ} \mathrm{C}$. The supernatants were evaluated for their ability to convert benzoate, $2 \mathrm{CB}, 3 \mathrm{CB}$ and $4 \mathrm{CB}$, according to the method of Romanov \& Hausinger (1994) except that the reaction mixture, with a total volume of $2 \mathrm{ml}$, contained $1 \mathrm{mM}$ aromatic substrate and about $30-40 \mathrm{mg}$ protein in addition to $5 \mathrm{mM} \mathrm{Na}-\mathrm{MES}$ ( $\mathrm{pH}$ 6.5), $10 \mathrm{mM} \mathrm{Fe}\left(\mathrm{NH}_{4}\right)_{2}\left(\mathrm{SO}_{4}\right)_{2}, 100 \mathrm{mM}$ NADH and $2 \mu \mathrm{M}$ FAD. Aliquots of $500 \mu \mathrm{l}$, which were taken at the initiation of the reaction and at 15 or $30 \mathrm{~min}$ thereafter, were immediately added to $86 \mu \mathrm{l} 7 \mathrm{M}$ trichloroacetic acid in microtubes to precipitate the proteins. Samples were prepared for quantitative HPLC analysis according to Fetzner et al. (1989) by adjusting the supernatant $\mathrm{pH}$ to about 6 with $5 \mathrm{M}$ sodium hydroxide. After a second centrifugation, samples were diluted with 1 vol. HPLC solvent. (Chloro)benzoate dioxygenase activity of the supernatant was determined by measuring substrate consumption in the supernatant by HPLC (HP1100; Hewlett Packard) on an Eclipse XDB-C18 (Agilent Technologies) reversed phase column, using acetonitrile: $10 \mathrm{mM}$ $\mathrm{H}_{3} \mathrm{PO}_{4}(50: 50, \mathrm{v} / \mathrm{v})$ as the solvent at a flow rate of $1 \mathrm{ml} \mathrm{min} \mathrm{m}^{-1}$. Authentic benzoate, 2CB, 3CB, 4CB and catechol (all purchased from Wako Pure Chemicals), and 3-chlorocatechol (3CC) and 4-chlorocatechol (4CC) (both purchased from Tokyo-Kasei) standards were run to verify their respective retention times.

Construction of NK8 cbeA, cbeR and catA disruptant strains. These disruptants were generated by omega $(\Omega)$ cassette interposon mutagenesis following the method of Schweizer (1992). In all gene disruptants, internal fragments of considerable length were excised, i.e. the 603 bp PstI-HincII fragment in $c b e A$, the 341 bp StuI-EcoRI fragment in cat $A$ and the 473 bp SphI-NruI fragment in cbeR, and replaced by the 1721 bp HindIII $\Omega$ gentamicin-resistance $\left(\mathrm{Gm}^{\mathrm{r}}\right)$ cassette $(\Omega \mathrm{aac})$ of pHP45aac, the $1773 \mathrm{bp}$ SmaI $\Omega$ aac cassette of pHP45aac and the $2267 \mathrm{bp}$ HindIII $\Omega$ hygromycin-resistance $\left(\mathrm{Hm}^{\mathrm{r}}\right)$ cassette ( hygg) of pHP45hyg (Blondelet-Rouault et al., 1997), respectively. In all constructs, DNA fragments ranging from 1.5 to $2 \cdot 2 \mathrm{~kb}$ flank the $\Omega$ cassette. The gene constructs and the MOB cassette of pMOB3 were sequentially cloned into pNOT322, which was used to transform E. coli strain S17-1 ipir. Conjugation of the transformed S17-1 ipir with NK8 cells was done according to Franklin (1985). Transconjugants were selected at $30^{\circ} \mathrm{C}$ on DA agar plates containing gentamicin or hygromycin and were evaluated on DA agar plates with the appropriate antibiotic to separate double from single cross-overs. Allelic replacement of the wild-type genes by the $\Omega$ cassette-disrupted genes was verified by Southern hybridization analysis. Disruptants were evaluated for their ability to grow on benzoate, $3 \mathrm{CB}$ and $4 \mathrm{CB}$ containing the appropriate antibiotic. NK8 strains disrupted in their cbeA, cat $A$ and $c b e R$ genes were named NDBA1, NCAD and NCRD, respectively.

Complementation of the cbeA disruptant. The $12.5 \mathrm{~kb}$ HindIII-EcoRI fragment of NK8 that carries the cbe-cat gene cluster was cloned into the broad-host-range plasmid vector pJRD215 (Davison et al., 1987) to generate plasmid pBAC1, which was utilized to transform E. coli S17-1. The E. coli S171 transformant was conjugated with the NK8 cbeA disruptant NDBA1. Transconjugants of NDBA1 were evaluated for their ability to utilize benzoate, $3 \mathrm{CB}$ or $4 \mathrm{CB}$ as the sole carbon source.

Expression of NK8 cbeABCD in E. coli. The NK8 cbeABCD gene cluster was amplified by PCR with the 77-mer forward primer 5'-CCTCTAGAAATAATTTTGTTTAACTTTAAGAAGGAGATATACCATGTCCGCCATCACCGACA AAGCCAGTCAGCTCG-3' and the 29-mer reverse primer 5'-CAGGATCCATAGCGAATCTTCTCGTACAC-3'. The amplified fragment was digested with $\mathrm{XbaI} / \mathrm{BamHI}$ and cloned into the $\mathrm{XbaI} / \mathrm{BamHI}$ sites of $\mathrm{pET} 14 \mathrm{~b}$ to generate plasmid p14BEP. E. coli strain HMS174(DE3) was transformed with p14BEP carrying the correct fragment, as verified by sequencing. Transformants were cultured overnight at $30^{\circ} \mathrm{C}$ in $2 \times \mathrm{YT}$ medium (Sambrook et al., 1989) containing ampicillin. The cultures were diluted 50 -fold with pre-warmed fresh $2 \times$ YT-ampicillin medium and again grown at $30{ }^{\circ} \mathrm{C}$ to an $\mathrm{OD}_{600}$ of $0 \cdot 4-0 \cdot 6$, at which point IPTG was added to a final concentration of $0.5 \mathrm{mM}$ to induce expression of the cbe $A B C D$ genes. After $3 \mathrm{~h}$ of culture with the inducers, cells were harvested, washed three times with $20 \mathrm{mM}$ potassium phosphate buffer $\left(\mathrm{pH} \mathrm{7.5)}\right.$ and stored at $-80^{\circ} \mathrm{C}$ until used for the preparation of crude cell-free extracts for enzyme assay by HPLC.

Determination of the products of CbeABCD. Products generated from (chloro)benzoates by CbeABCD were determined using whole cells of E. coli HMS(DE3)/p14BEP. Cells freshly harvested from $150 \mathrm{ml}$ culture grown as described above were washed with 1 vol. $20 \mathrm{mM}$ potassium phosphate buffer ( $\mathrm{pH} 7.5$ ) and resuspended in $45 \mathrm{ml}$ of the buffer. To aliquots of $10 \mathrm{ml}$, substrates were added to a final concentration of $2 \mathrm{mM}$ and the reaction mixtures were incubated at $30^{\circ} \mathrm{C}$ in a shaking water bath. Samples $(1 \mathrm{ml})$ taken at selected time points were immediately centrifuged at $20000 \mathrm{~g}$ for $10 \mathrm{~min}$ at $4{ }^{\circ} \mathrm{C}$. Aliquots $(500 \mu \mathrm{l})$ of the supernatant were mixed with an equal volume of HPLC solvent, centrifuged and subjected to HPLC analysis at $A_{203}$.

Transcriptional fusion studies. Various DNA fragments from the NK8 cbe-cat region were ligated immediately upstream of the promoterless lacZ gene of the reporter plasmid pQF50 (Farinha \& Kropinski, 1990) to generate several lacZ transcriptional fusion plasmids as shown in Fig. 3. The plasmid pFJ50cbeRcatAcbeA' contains the complete $c b e R$ and catA genes and the truncated cbeA gene fused to lacZ; pFJ50cbeRcatA:: $\Omega$ hygcbeA' differs from pFJ50cbeRcatAcbeA' in having its cat $A$ gene disrupted by the Shyg cassette; pFJ50cbeR'catAcbeA' is similar to pFJ50cbeRcatAcbeA' except that $c b e R$ is incomplete; in pFJ50cbeR'cat $\mathrm{A}^{\prime}$ and $\mathrm{pFJ} 50 \mathrm{cbeRcat} \mathrm{A}^{\prime}$, the truncated cat $A$ is fused to $l a c Z$. These lac $Z$ transcriptional fusion plasmids were introduced by electroporation into PRS4020, the catR knockout mutant of P. putida (Parales \& Harwood, 1993). Transformed PRS4020 cells were assayed for $\beta$-galactosidase activity. Induction of the lacZ gene in PRS4020 transformants was performed by pre-culturing the cells overnight at $30^{\circ} \mathrm{C}$ on LB medium containing gentamicin and carbenicillin. One hundred microlitres of the pre-culture was used to inoculate $10 \mathrm{ml}$ basal synthetic medium (Aldrich et al., 1987) containing $10 \mathrm{mM}$ glucose (BSMG), or BSMG supplemented with $5 \mathrm{mM}$ benzoate, 3CB or $4 \mathrm{CB}$, or with 0.1 or $0.05 \mathrm{mM}$ catechol, or $5 \mathrm{mM}$ cis,cis-muconate (Celgene), then grown for $17 \mathrm{~h}$ at $30{ }^{\circ} \mathrm{C}$. $\beta$-Galactosidase activity was assayed according to the method of Miller (1972). All assays were done in triplicate. $\beta$ Galactosidase activity was expressed in Miller units [nmol nitrophenol generated $\min ^{-1}$ (mg protein $)^{-1}$ ].

NK8 cbeA:: lacZ-Km ${ }^{r}$ disruptant. To determine the inducer(s) of expression of cbeA in NK8, the $4.73 \mathrm{~kb}$ lacZ- $\mathrm{Km}^{\mathrm{r}}$ cassette of pKOK6.1, a derivative of pKOK6 (Kokotek \& Lotz, 1989), was inserted into the EcoRV site of $c b e A$ by allelic replacement 
(see Fig. 1) (Schweizer, 1992). The procedure was essentially the same as those for the gene disruption by the $\Omega$ interposon described above. In the final construct in pNOT322, into which the MOB cassette of pMOB3 was also inserted, the lac $Z-\mathrm{Km}^{\mathrm{r}}$ cassette is flanked by 1.65 and $2 \cdot 17 \mathrm{~kb}$ NK8 DNA fragments carrying the $c b e A$ fragments to facilitate crossing over. Disruptants were verified by Southern hybridization analysis. NBALZ, the cbeA:: lacZ- $\mathrm{Km}^{\mathrm{r}}$ disruptant, was cultured in BSMG alone or in BSMG supplemented with $5 \mathrm{mM}$ benzoate, $2 \mathrm{CB}, 3 \mathrm{CB}$ or $4 \mathrm{CB}$, or with $0 \cdot 1 \mathrm{mM}$ catechol or $5 \mathrm{mM}$ cis,cis-muconate. The $\beta$-galactosidase activity was measured as described above. Supernatants of aliquots of NBALZ cells grown with the various substrates were subjected to quantitative HPLC determination of possible degradation of the inducers before the lacZ assay was conducted.

\section{RESULTS}

\section{Growth characteristics of NK8 on (chloro)benzoate media}

Burkholderia sp. strain NK8 was isolated from a soil sample in Japan, under conditions in which 3CB was the sole source of carbon and energy. The strain grew abundantly on solid and liquid media containing $3 \mathrm{CB}$, $4 \mathrm{CB}$ or benzoate as the sole carbon source. There was, however, no growth on 2CB.

At a concentration of $5 \mathrm{mM}$ substrate in batch cultures, NK8 cells pre-cultured in $3 \mathrm{CB}$ grew fastest in $3 \mathrm{CB}$ medium, with a doubling time of approximately $4 \mathrm{~h}$. Growth with 4CB and benzoate were slower, with doubling times of about 5.5 and $11 \mathrm{~h}$, respectively. Interestingly, the lag phase with $4 \mathrm{CB}$ was rather long, reaching about $45 \mathrm{~h}$ in batch cultures inoculated with 3CB-grown cells. Corresponding values for benzoate and $3 \mathrm{CB}$ are 20 and $10 \mathrm{~h}$, respectively. The reason for the long lag phase with $4 \mathrm{CB}$ is not clear. Even in batch cultures inoculated with 4CB-grown cells, the lag phase in $4 \mathrm{CB}$ was consistently longer than those in $3 \mathrm{CB}$ and benzoate media. Nevertheless, once the exponential phase commenced, NK8 cells grew rapidly, and as in $3 \mathrm{CB}$ medium, the transition to stationary phase in $4 \mathrm{CB}$ was clearly defined.

\section{Degradation of chlorobenzoates}

NK8 cells grown on succinate, benzoate or 3CB were disrupted by sonication and the supernatants were subjected to enzyme assay. The lysate of NK8 cells grown on succinate did not transform benzoate, $2 \mathrm{CB}$, $3 \mathrm{CB}$ or $4 \mathrm{CB}$ (Table 2), indicating the absence of constitutive expression of the chlorobenzoate dioxygenase genes. Lysates of benzoate- or 3CB-grown cells, on the other hand, showed considerable conversion of the aromatic substrates. The relative activities for the chlorobenzoates are not remarkably different between benzoate- and 3CB-grown NK8 cells. It is noteworthy that the activity of $\mathrm{NK} 8$ cell lysate against $2 \mathrm{CB}$ is comparable to that against $3 \mathrm{CB}$. These data suggest that NK8 has a (chloro)benzoate dioxygenase that possesses a broad substrate specificity.

\section{Cloning and sequencing of the chlorobenzoate dioxygenase genes}

The nucleotide sequence of the $500 \mathrm{bp}$ PCR product of the primer pair BAf1/BAr2 on NK8 is similar to both $x y l X(67 \cdot 8 \%)$ of the plasmid pWW0 and benA $(59 \cdot 4 \%)$ of Acinetobacter sp. ADP1. Probing NK8 genomic DNA for benzoate dioxygenase genes with this PCR product resulted in the cloning of a $5.3 \mathrm{~kb}$ EcoRI fragment (Fig. 1). Using the left end of this fragment as the probe, the overlapping $8 \cdot 1 \mathrm{~kb}$ HindIII-PstI fragment was cloned. These two overlapping fragments span a $12.5 \mathrm{~kb}$ DNA region (Fig. 1).

Table 2. Oxidation of (chloro)benzoates by Burkholderia sp. NK8 (chloro)benzoate dioxygenase

NK8 cells were grown to late exponential phase on $5 \mathrm{mM}$ succinate, benzoate or 3-chlorobenzoate while E. coli HMS174(DE3) cells harbouring the cbeABCD genes in pET14B were cultured on LB and induced with $0.5 \mathrm{mM}$ IPTG. The cells were harvested by centrifugation, washed, sonicated and ultracentrifuged. The crude protein extracts were examined for their oxidation activity against $1 \mathrm{mM}$ (chloro) benzoates. Specific activity, which is given only for benzoate, was based on the amount of substrate consumed as determined by HPLC. Relative activity was estimated using benzoate activity as the standard. Data reported are means \pm SD of three replicates.

\begin{tabular}{|llcccc|}
\hline \multirow{2}{*}{ Strain } & $\begin{array}{l}\text { Growth } \\
\text { medium }\end{array}$ & \multicolumn{4}{c|}{ Relative oxidation activity (\%) against: } \\
\cline { 3 - 6 } & & Benzoate & 2 CB & 3CB & 4CB \\
& Succinate & 0 & 0 & 0 & 0 \\
NK8 & Benzoate & $100(3 \cdot 18 \pm 0 \cdot 07)^{*}$ & $28 \pm 1 \cdot 7$ & $34 \pm 0 \cdot 8$ & $46 \pm 2 \cdot 7$ \\
NK8 & 3CB & $100(1 \cdot 34 \pm 0 \cdot 01)^{*}$ & $34 \pm 1 \cdot 5$ & $29 \pm 2 \cdot 1$ & $61 \pm 4 \cdot 4$ \\
NK8 & LB/IPTG & $100(2 \cdot 40 \pm 0 \cdot 05)^{*}$ & $14 \pm 1 \cdot 9$ & $42 \pm 3 \cdot 0$ & $76 \pm 7 \cdot 3$ \\
E. coli/cbeABCD & &
\end{tabular}

*Specific activity [nmol substrate oxidized $(\mathrm{mg} \text { protein })^{-1} \mathrm{~min}^{-1}$ ]. 


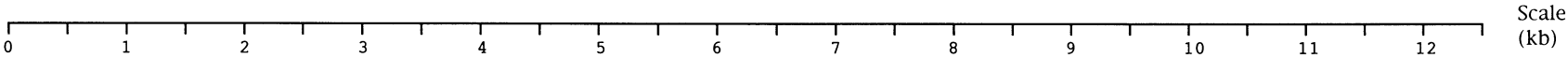

(a)

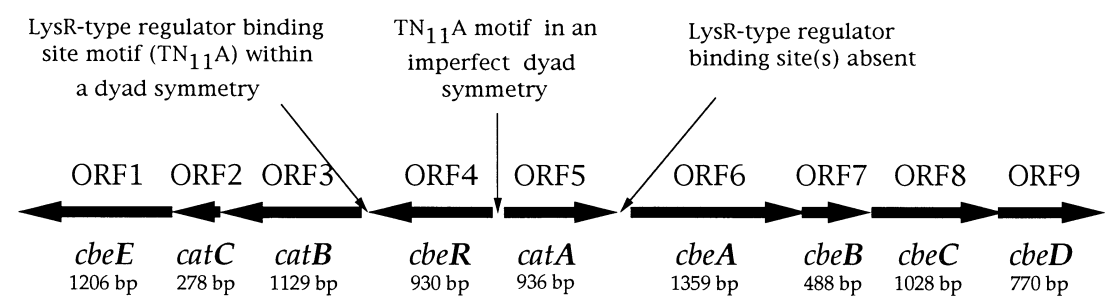

HindIII-PstI fragment, $8.1 \mathrm{~kb}$

EcoRI fragment, $5.3 \mathrm{~kb}$

(b)

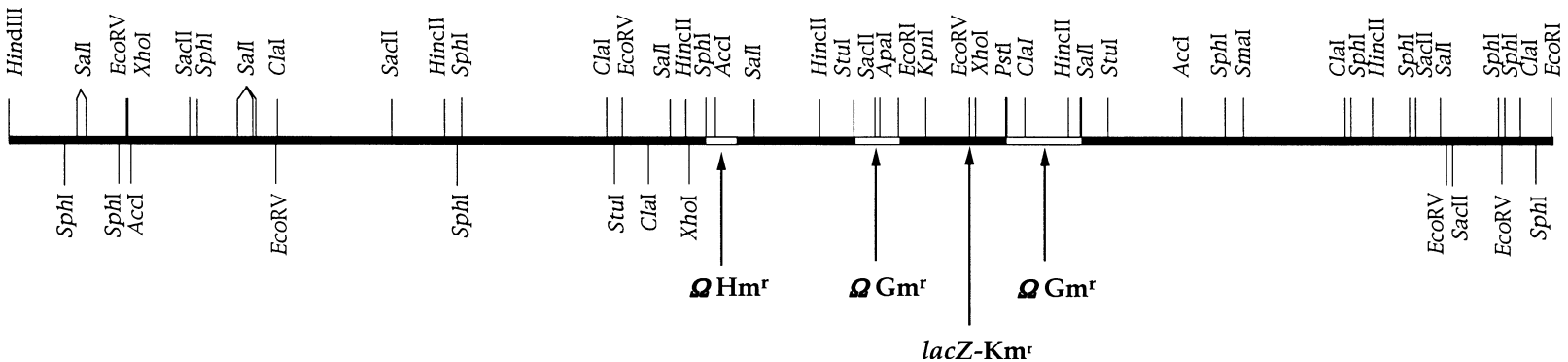

Fig. 1. Organization of the chlorobenzoate (cbe) and catechol (cat) catabolic genes (a) clustered on the $12.5 \mathrm{~kb}$ HindIII-ECoRI genomic DNA region (b) of Burkholderia sp. strain NK8. Also shown in (a) are the approximate locations of the putative LysR-type transcriptional regulator binding sites and the length of each gene in the cluster. In (b), the two overlapping horizontal lines parallel to the restriction map represent the overlapping DNA fragments cloned in pBluescript II KS $(+)$, heavy arrows indicate the points of insertion of the omega $(\Omega)$ and lacZ-Km ${ }^{r}$ interposon cassettes used for gene disruption and white segments on the restriction map represent gene fragments replaced by the $\Omega$ cassette.

Table 3. Identities (\%) in deduced amino acid sequences between the NK8 CbeABCD proteins and their respective homologues in some class IB aromatic ring hydroxylases

\begin{tabular}{|c|c|c|c|c|c|}
\hline \multirow{2}{*}{$\begin{array}{l}\text { NK8 Cbe } \\
\text { protein }\end{array}$} & \multicolumn{5}{|c|}{ Homologue* } \\
\hline & $\begin{array}{c}\text { Cbd } \\
(\mathrm{ABC})\end{array}$ & $\begin{array}{c}\text { Xyl } \\
(\mathrm{XYZL})\end{array}$ & $\begin{array}{c}\text { Ben } \\
(\mathrm{ABCD})\end{array}$ & $\begin{array}{c}\text { Ant } \\
(\mathrm{ABC})\end{array}$ & $\begin{array}{r}\mathrm{Tft} \\
(\mathrm{AB})\end{array}$ \\
\hline CbeA & $64 \cdot 3$ & $58 \cdot 2$ & $57 \cdot 1$ & $45 \cdot 1$ & $38 \cdot 7$ \\
\hline CbeB & $56 \cdot 2$ & $60 \cdot 5$ & $52 \cdot 2$ & $39 \cdot 9$ & $38 \cdot 9$ \\
\hline CbeC & $45 \cdot 1$ & $54 \cdot 2$ & $49 \cdot 7$ & $37 \cdot 8$ & - \\
\hline CbeD & - & $57 \cdot 0$ & $56 \cdot 4$ & - & - \\
\hline
\end{tabular}

*Homologous proteins: CbdABC (2-halobenzoate 1,2dioxygenase) of Burkholderia cepacia 2CBS (Haak et al., 1995), X79076; XylXYZ (toluate 1,2-dioxygenase) and XylL (toluate diol dehydrogenase) of Pseudomonas putida mt-2 TOL plasmid pWW0 (Harayama et al., 1991), M64747; BenABC (benzoate 1,2dioxygenase) and BenD (DHB dehydrogenase) of Acinetobacter, sp. ADP1 (Neidle et al., 1987), AF009224; AntABC (anthranilate dioxygenase) of Acinetobacter sp. ADP1 (Bundy et al., 1998), $\mathrm{AF} 071556$; and TftAB (2,4,5-trichlorophenoxyacetate oxygenase) of Burkholderia cepacia AC1100 (Danganan et al., 1994), U11420. $\mathrm{Cbd}$, Ben and Xyl can oxidize benzoate, while Ant and Tft transform anthranilate and trichlorophenoxyacetate, respectively.
Nucleotide sequence analysis of this $12 \cdot 5 \mathrm{~kb}$ DNA region revealed the presence of 9 ORFs. ORFs 5-9 are transcribed in the same direction (from left to right in Fig. 1), while ORFs 1-4 are transcribed divergently. After comparisons with related sequences in the database, ORFs 6-9 were designated $c b e A, c b e B$, cbeC and $c b e D$, respectively (Fig. 1). CbeA showed the highest amino acid sequence identity to CbdA (64\%) (Table 3), the large subunit of the terminal oxygenase of the 2halobenzoate 1,2-dioxygenase of B. cepacia 2CBS (Haak et al., 1995); CbeB to XylY (60\%), the small subunit of the terminal oxygenase of toluate 1,2-dioxygenase of $P$. putida TOL plasmid pWW0 (Harayama et al., 1991); and $\mathrm{CbeC}$ to XylZ (54\%), the reductase component of toluate 1,2-dioxygenase. Probably, CbeABC comprise an aromatic ring hydroxylase that belongs to group IB of Batie's classification (Batie et al., 1992) as indicated by its closeness to the above-mentioned group IB hydroxylases. $c b e D$ encodes a protein with an amino acid sequence that resembles those of the cis-diol dehydrogenase encoded by $x y l L$ on the TOL plasmid pWW0 $(57 \%$ identity) and benD in Acinetobacter sp. ADP1 (56\% identity).

The deduced amino acid sequence of ORF5 is most similar $(82 \%)$ to the catA2 gene of Acinetobacter lwoffii 

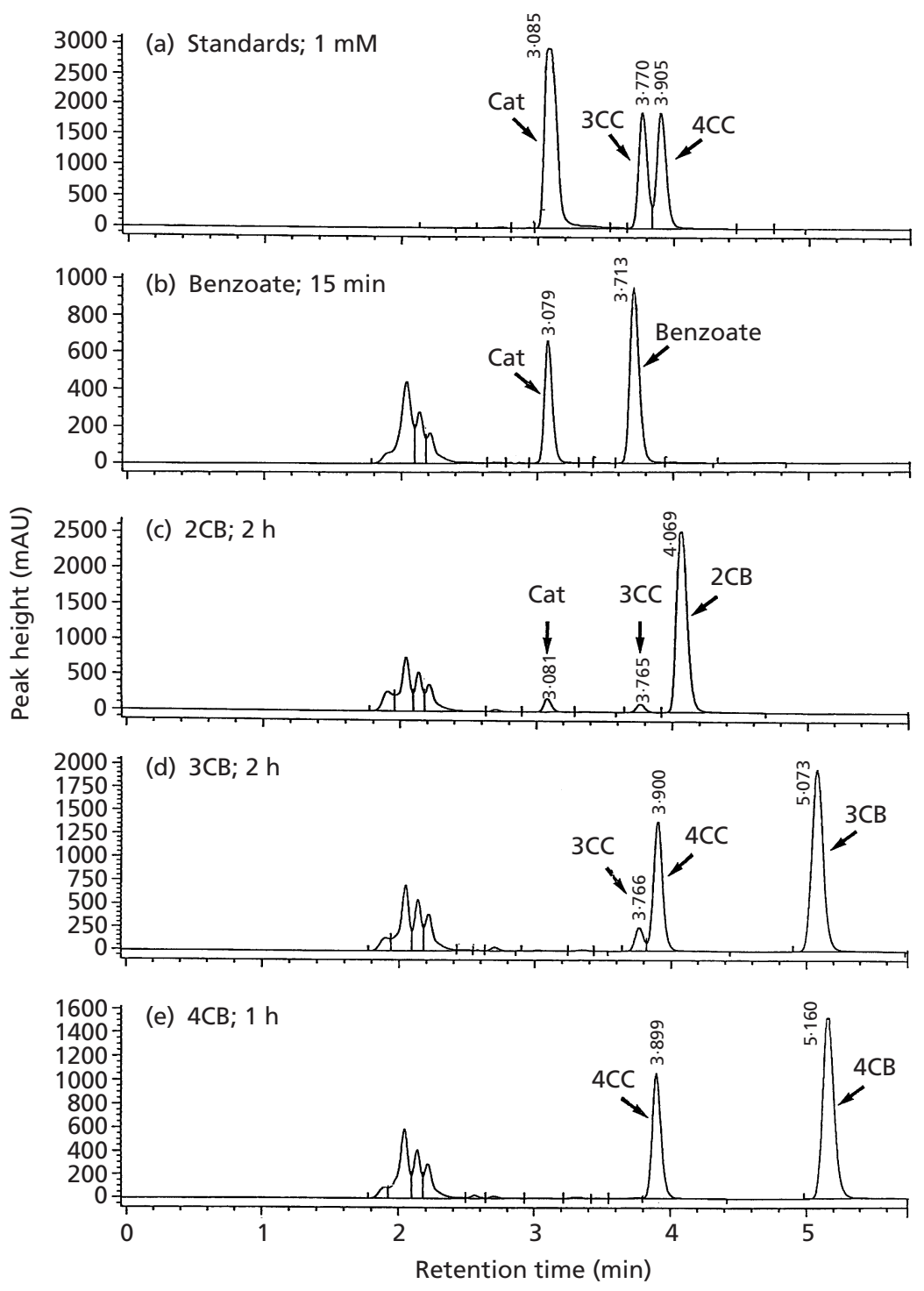

Fig. 2. Oxidation products of benzoate (b), $2 C B(c), 3 C B(d)$ and $4 C B(e)$ resulting from the IPTG-induced expression of the NK8 (chloro)benzoate dioxygenase genes $c b e A B C$ in $E$. coli. Data were obtained from HPLC analysis at $A_{203}$ of the substrates subjected to conversion by LB-grown $E$. coli HMS174(DE3) cells harbouring the NK8 $c b e A B C D$ genes in the plasmid p14BEP. Initial substrate concentration was $2 \mathrm{mM}$. Data shown are for samples taken at the indicated times. Peaks visible in (a) are those for catechol (Cat), 3-chlorocatechol (3CC) and 4-chlorocatechol (4CC) standards.
K24 (Kim et al., 1997). ORF5 was thus designated catA. ORF4 is a $935 \mathrm{bp}$ gene divergently transcribed from cat $A$ (Fig. 1). Its deduced amino acid sequence shares high identity with LysR-type transcriptional regulators involved in benzoate or catechol catabolism such as $\mathrm{ORF}_{\mathrm{R} 2}(55 \%)$ of one of the two catechol gene clusters of Frateuria sp. ANA-18 (Murakami et al., 1999), catR of P. putida PRS2000 (50\%) (Houghton et al., 1995) and RB1 (48\%) (Rothmel et al., 1990), and benM (48\%) and catM $(45 \%)$ of ADP1 (Collier et al., 1998; RomeroArroyo et al., 1995). NK8 ORF4 was named cbeR because subsequent results showed that the gene is involved in (chloro)benzoate catabolism, and that it responds to $3 \mathrm{CB}, 4 \mathrm{CB}$ and benzoate, as well as cis,cismuconate.

The deduced amino acid sequences of ORFs 2 and 3 are similar to those of catC (63\% identity) and catB $(57 \%$ identity), respectively, of ADP1. Therefore, they were designated $\operatorname{cat} C$ and $c a t B$, respectively. ORF1 encodes a protein with a deduced amino acid sequence that is $55 \%$ identical to that of benE of ADP1, the function of which is unknown (Collier et al., 1998). The gene was named cbeE.

\section{cbe $A$ disruption and complementation}

To ascertain the function of the cbeABCD gene cluster in chlorobenzoate catabolism, cbeA was disrupted by $\Omega$ interposon mutagenesis (Fig. 1). The disruption was confirmed by Southern hybridization. The disruptant strain NDBA1 failed to grow on $3 \mathrm{CB}, 4 \mathrm{CB}$ or benzoate, the substrates degraded by the wild-type strain NK8. This observation indicates that $c b e A$ is involved in the catabolism of benzoate and monochlorobenzoates. The disruptant strain NDBA1 was complemented by the 
$12.5 \mathrm{~kb}$ HindIII-EcoRI fragment containing the $c b e-c a t$ gene cluster harboured by pBAC1. The complemented disruptant (NDBA1/pBAC1) grew on benzoate, 3CB and 4CB (data not shown), indicating that the cbe-cat DNA region restored in the disruptant the ability to catabolize benzoate and monochlorobenzoates.

\section{Expression of $c b e A B C D$ in $E$. coli}

E. coli HMS174(DE3) transformed with p14BEP, a derivative of expression vector $\mathrm{pET} 14 \mathrm{~b}$ which carries the cbeABCD genes, was cultured in the presence of IPTG to induce the expression of the genes. The cells were harvested, washed and disrupted by sonication. Cell-free extracts transformed 2CB, 3CB, 4CB and benzoate. Activity was greatest for benzoate followed by $4 \mathrm{CB}, 3 \mathrm{CB}$ and $2 \mathrm{CB}$ (Table 2). While the value for $2 \mathrm{CB}$ is relatively low compared to those of $\mathrm{NK} 8$ cell lysates, this result, together with that of the disruption of $c b e A$, confirms that the cbeABCD genes are involved in the oxidation of 2CB, 3CB, 4CB and benzoate in NK8.

Analysis of HPLC peaks emerging during enzyme reaction by whole cells of $E$. coli cbe $A B C D^{+}$showed that benzoate generates catechol while $4 \mathrm{CB}$ produces 4CC. Oxidation of $3 \mathrm{CB}$ gives rise to 4CC and 3CC as the major and minor intermediate products of oxidation, respectively (Fig. 2), while $2 \mathrm{CB}$ yields not only $3 \mathrm{CC}$ but also catechol (apparently in equal amounts), suggesting that CbeABC lacks absolute regiospecificity.

\section{Disruption of cbeR and catA}

In the cbe-cat gene cluster, the single regulatory gene $c b e R$ lies upstream of and divergently transcribed from $c a t A$. The function of $c b e R$ in the transformation of benzoate and chlorobenzoates was determined by disrupting the gene through interposon mutagenesis with the $\Omega$ byg cassette (Fig. 1). NCRD, the cbeR disruptant, simultaneously lost the ability to grow on $3 \mathrm{CB}, 4 \mathrm{CB}$ and benzoate (data not shown), suggesting that $c b e R$ regulates the expression of the $c b e$ genes. The cat A disruptant strain NCAD, which was generated by interposon mutagenesis with the $\Omega a a c$ cassette, likewise failed to grow on benzoate and chlorobenzoates. The probability that the disruption of cat $A$ prevented the transcription of the cbe $A B C D$ genes located downstream of cat $A$, such that the $c b e A B C D$ genes were not expressed, was confirmed by later experiments (Figs 3 and 4).

\section{CbeR-meditated regulation of catA expression}

The function of $c b e R$ in the expression of the $c b e$ and $c a t$ genes was examined using various $l a c Z$ transcriptional fusion constructs in the reporter plasmid pQF50 (Fig. 3). PRS4020, the catR knock-out mutant of P. putida (Parales \& Harwood, 1993), was used as the host for the lac Z reporter gene assay, since introduction of pQF50 derivatives into NK8 was unsuccessful. With PRS4020 as the host, the possibility of cross-activation of the

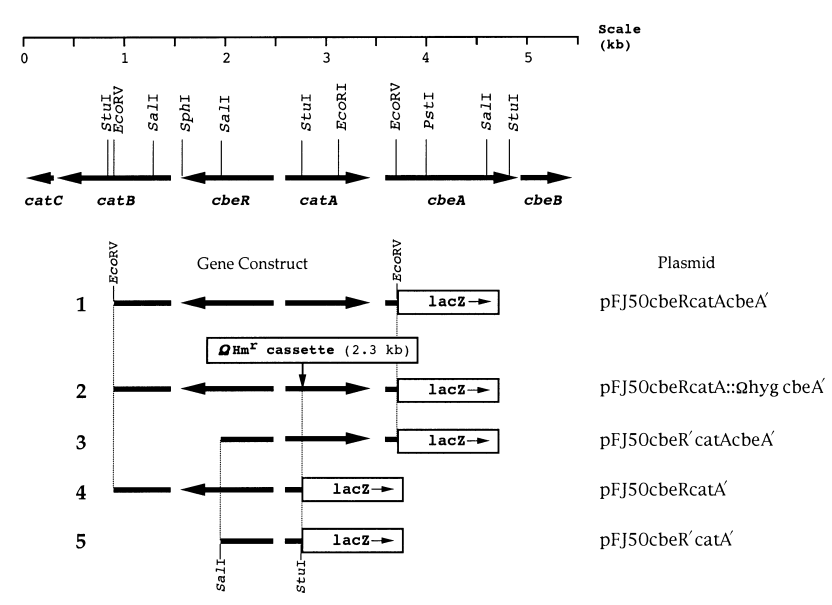

Fig. 3. Diagrams of the cbe-cat lacZ fusion constructs in pQF50. Shown are the NK8 DNA fragments cloned at the multicloning site of pQF50 immediately upstream of its promoterless lac $Z$ gene. In the designated names of the pQF50-derived plasmids, the prime sign (') indicates that the gene bearing it is truncated. In construct number 2, cat $A$ transcription was blocked by the insertion of the $2.3 \mathrm{~kb} \Omega$ hyg cassette at the Stul site of catA. The organization of the cat-cbe genes is given for reference. Only the NK8 genes are drawn to scale.

genes from the host-encoded catR could be eliminated. In these PRS4020 transformants, $\beta$-galactosidase activity reflects the expression of $c b e A$ or $c a t A$. When grown in BSMG medium supplemented with either benzoate, $3 \mathrm{CB}$ or 4CB, PRS4020 cells harbouring pFJ50 cbeRcatAcbeA' and $\mathrm{pFJ} 50 \mathrm{cbeRcat} \mathrm{A}^{\prime}$, both having an intact cbeR, exhibited $\beta$-galactosidase activity increased 60 - to 100 fold compared to those grown in the absence of the inducers (Fig. 4). The cells harbouring plasmids with the truncated $c b e R$, i.e. pFJ50cbeR'catAcbeA' or $\mathrm{pFJ} 50 \mathrm{cbeR}^{\prime}$ cat $\mathrm{A}^{\prime}$, did not elicit induction of $\beta$ galactosidase activity in the presence of $3 \mathrm{CB}, 4 \mathrm{CB}$ or benzoate. $2 \mathrm{CB}$ did not induce $\beta$-galactosidase activity regardless of the presence or absence of $c b e R$ (data not shown). In a separate experiment involving the plasmids pFJ50cbeRcatAcbeA' and pFJ50cbeR'catAcbeA', it was evident that catechol and cis,cis-muconate likewise induce considerable levels of $\beta$-galactosidase activity (data not shown). The above results indicate that benzoate, 3CB, 4CB, catechol and cis, cis-muconate can induce the expression of $c a t A$ and $c b e A(B C)$ genes in a $P$. putida PRS4020 background. Moreover, this evidence shows that CbeR is essential for the expression of catA and $c b e A$.

\section{Co-expression of the cbe $A$ and cat $A$ genes}

In strain NK8, cat $A$ and $c b e A$ are separated from each other by only $115 \mathrm{bp}$, and both lie upstream of and are transcribed divergently from $c b e R$ (Fig. 1). Neither the -10 and -35 bacterial promoter-like sequences nor the consensus motif of LysR-type regulator recognition site exist in the catA-cbeA intergenic region. Thus, it is 


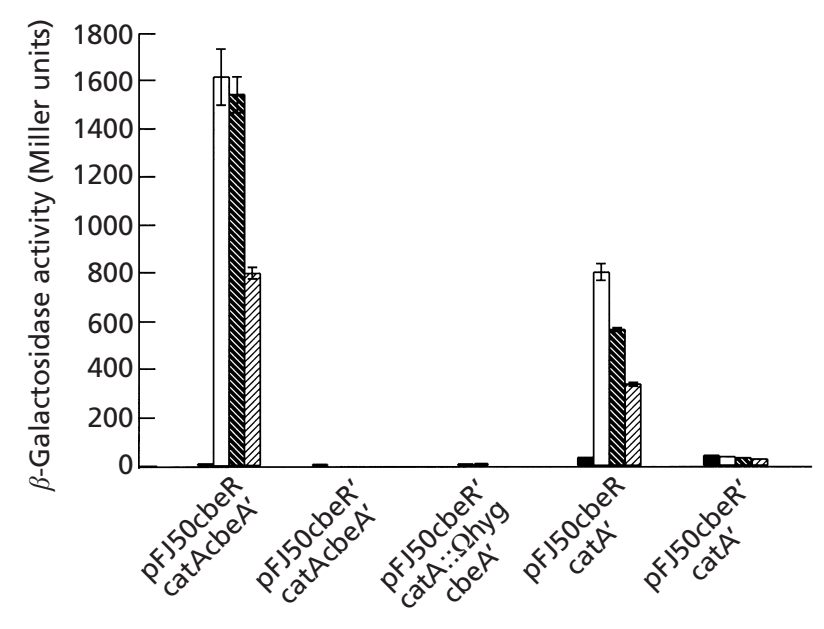

Fig. 4. $\beta$-Galactosidase activities resulting from the expression of the pQF50-derived NK8 cbe-cat lacZ fusion plasmid constructs in the catR knock-out mutant PRS4020 of $P$. putida. The cells were grown for $17 \mathrm{~h}$ in BSMG medium supplemented with inducers (black bars, no inducer; white bars, $5 \mathrm{mM}$ benzoate; black bars with white hatching, $5 \mathrm{mM} 3 \mathrm{CB}$; white bars with black hatching, $5 \mathrm{mM} \mathrm{4CB}$ ). Bars represent means of three replicates. Vertical lines on top of the bars indicate standard deviations from the means. See Fig. 3 for the details on the insert of each plasmid.

likely that cat $A$ and $c b e A$ are co-transcribed, a possibility that is further indicated by the inability of the cat $A$ disruptant NCAD to grow on (chloro)benzoates. To determine whether $c b e A$ transcription is initiated from the cat $A-c b e A$ intergenic region, the $\Omega b y g$ cassette was inserted into cat $A$ of the lac $Z$ transcriptional fusion plasmid $\mathrm{pFJ} 50 \mathrm{cbeRcatAcbeA}$ ' to generate pFJ50cbeRcatA:: :hygcbeA' (Fig. 3), which was then introduced into PRS4020. There was no induction of $\beta$ galactosidase activity even in the presence of inducers (Fig. 4), indicating that $c b e A$ is exclusively co-transcribed with catA.

\section{Inducers of $c b e A$ expression in NK8}

A cbeA::lacZ transcriptional fusion construct was introduced into the NK8 wild-type genome by allelic replacement to generate strain NBALZ. HPLC analysis confirmed that the cbeA disruption had blocked the conversion of $3 \mathrm{CB}, 4 \mathrm{CB}$ and benzoate by NBALZ. Addition of $3 \mathrm{CB}, 4 \mathrm{CB}$ or benzoate to the BSMG medium increased $\beta$-galactosidase activity by more than 70 -fold compared to those grown without these aromatics (Fig. $5)$. The addition of $2 \mathrm{CB}$, on the other hand, did not increase the activity. cis,cis-Muconate induced $\beta$ galactosidase activity to a level comparable to those induced by benzoate, $3 \mathrm{CB}$ or $4 \mathrm{CB}$. Catechol, added at a concentration low enough to allow NK8 growth, also induced $\beta$-galactosidase activity to a level almost half of those induced by benzoate, $3 \mathrm{CB}$ and $4 \mathrm{CB}$. On the other hand, 3CC and 4CC did not induce $\beta$-galactosidase

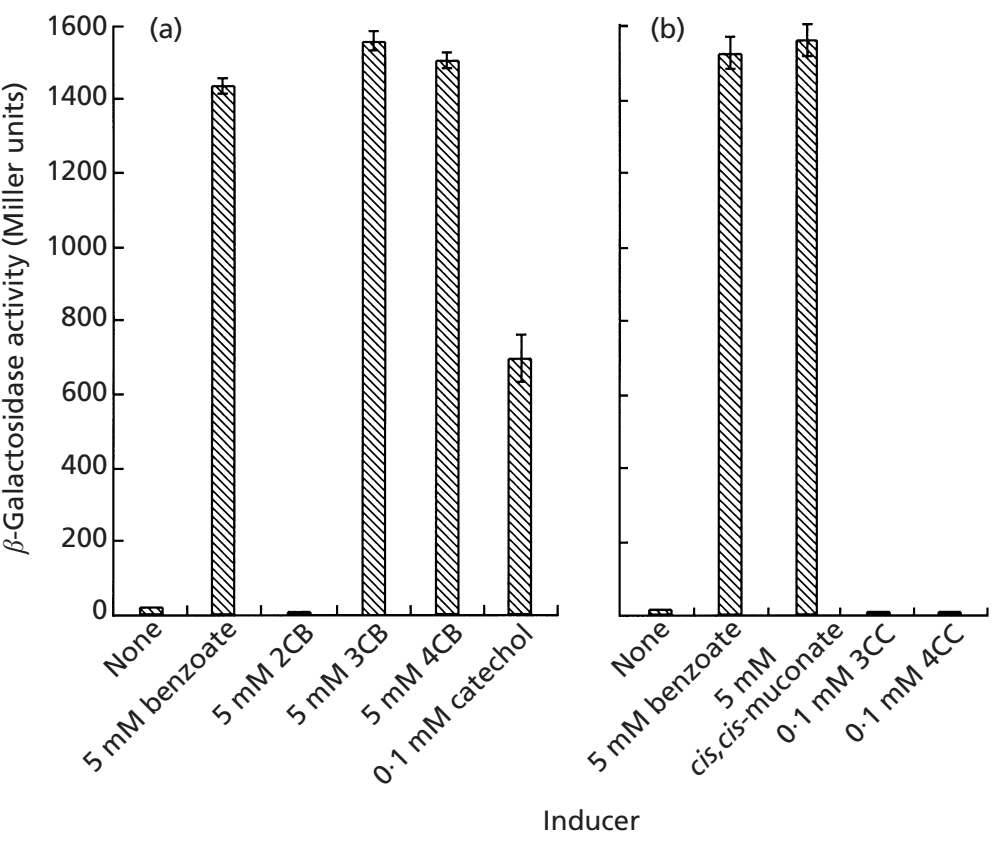

Fig. 5. $\beta$-Galactosidase activity of the NK8 cbeA::lacZ-Km ${ }^{r}$ disruptant. Cells were grown for $17 \mathrm{~h}$ in BSMG medium supplemented with the indicated inducers. Bars represent means of three replicates. Error bars represent standard deviations from the means. (a) and (b) are separate experiments.

activity. These results are consistent with those obtained with PRS4020 harbouring the transcriptional fusion plasmid pQF50 derivatives (Fig. 4), and thus confirm $3 \mathrm{CB}, 4 \mathrm{CB}$, benzoate and cis, cis-muconate as inducers of cbeA expression.

\section{DISCUSSION}

\section{The NK8 chlorobenzoate CbeABC has a broad substrate specificity}

The chlorobenzoate dioxygenase genes (cbeABC) involved in the transformation of benzoate, $3 \mathrm{CB}$ and $4 \mathrm{CB}$ were cloned from NK8 genomic DNA. The deduced amino acid sequence of NK8 chlorobenzoate dioxygenase $(\mathrm{Cbe} A B C)$ is $50-60 \%$ identical with those of the genetically characterized 2-halobenzoate dioxygenase (CbdABC) of B. cepacia 2CBS, benzoate dioxygenase (BenABC) of Acinetobacter sp. ADP1 and toluate dioxygenase (XylXYZ) of pWW0 (Table 3). Despite the similarities among these dioxygenases, the range of aromatics they oxidize is variable. The XylXYZ of $P$. putida $\mathrm{PaW} 1$, an $m$ - and $p$-toluate degrader, shows a broad substrate specificity, being able to transform $3 \mathrm{CB}$ and 4CB, but not 2CB (Reineke, 1998). The CbdABC of B. cepacia 2CBS apparently has broader substrate specificity, but its activity against $4 \mathrm{CB}$ is negligible (Fetzner et al., 1992). BenABC of Acinetobacter sp. 


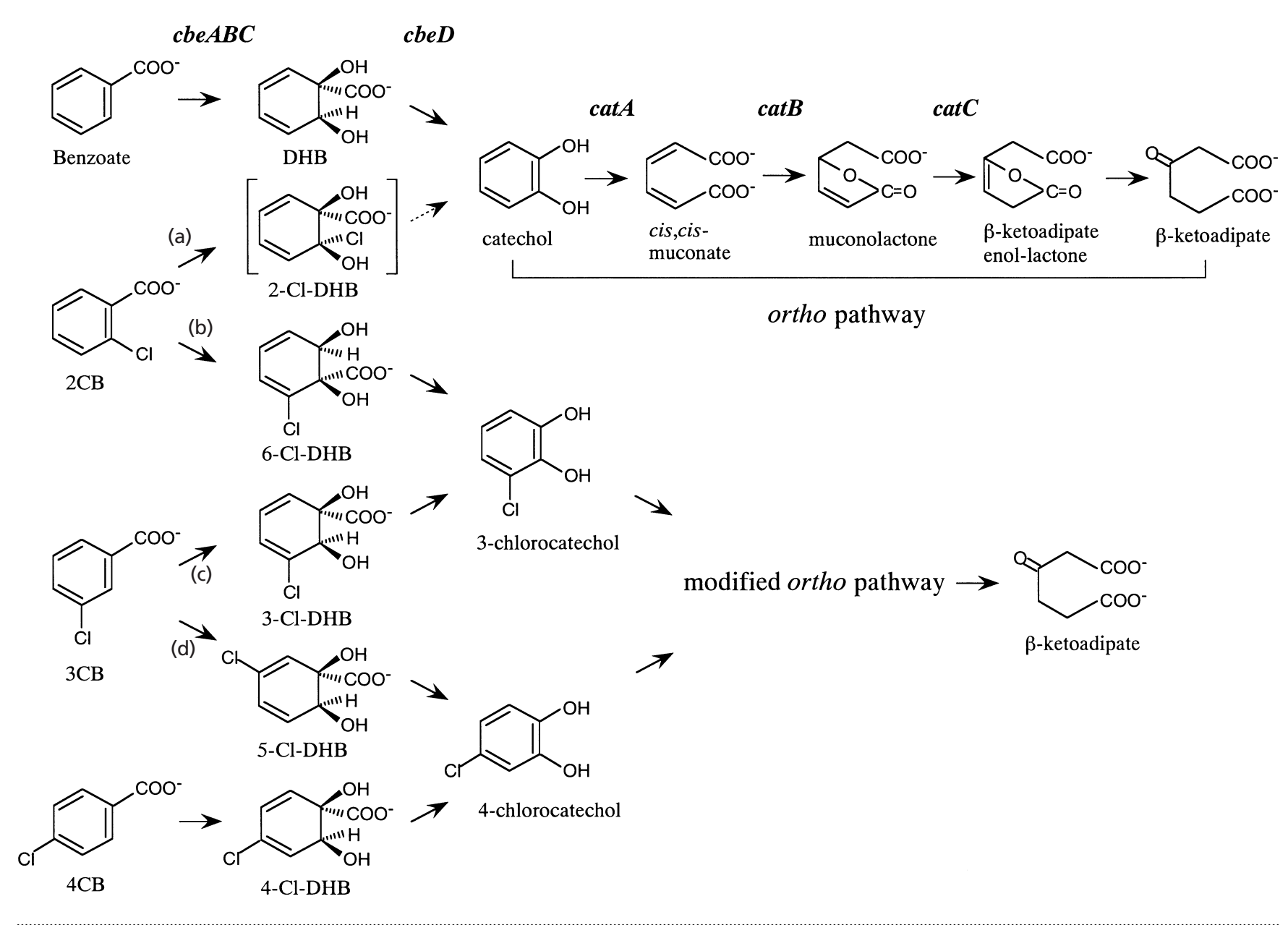

Fig. 6. Proposed degradation pathways for benzoate, $2 C B, 3 C B$ and $4 C B$ in Burkholderia sp. strain NK8. In the conversion of the asymmetrical aromatics $2 \mathrm{CB}$ and $3 \mathrm{CB}$, labelled arrows indicate steps in which $2 \mathrm{CB}$ binds with $\mathrm{CbeR}$ as $2 \mathrm{CB}$ (a) or ' $6 C B$ ' (b), and in which $3 C B$ binds as $3 C B$ (c) or ' $5 C B$ ' (d). The hypothetical 2-chloro-3,5-cyclohexadiene-1,2-diol-1carboxylic acid intermediate from $2 \mathrm{CB}$ (in square brackets) is presumed to spontaneously lose $\mathrm{Cl}^{-}$to generate catechol (dotted arrow). The catA gene may also participate in the conversion of 4CC into 3-chloro-cis,cis-muconate. The gene responsible for the conversion of $\beta$-ketoadipate enol-lactone to $\beta$-ketoadipate has not been identified.

ADP1, on the other hand, exhibits narrow substrate specificity, showing little or no oxidation of most substituted benzoates (Neidle et al., 1991). The 3CB degrader Pseudomonas sp. B13 grown on 3CB, and the benzoate degrader Ralstonia eutropha grown on benzoate, can degrade only $3 \mathrm{CB}$ in addition to benzoate (Reineke, 1998). The CbeABC of NK8 differs from these enzymes in that it can transform the three monochlorobenzoates almost equally well.

Similar or even greater ability to considerably transform all the monochlorinated benzoate isomers was previously reported for the toluate 1,2-dioxygenase of $B$. cepacia WR401, an o-toluate degrader (Reineke, 1998). However, notable differences between this enzyme and NK8 (chloro) benzoate dioxygenase are evident. Relative to benzoate, NK8 CbeABC activities against the three isomeric monochlorobenzoates ranged from 28 to $61 \%$ (Table 2), while WR401 has activities estimated from Reineke (1998) of approximately 90, 110 and 50\% for
2CB, 3CB and 4CB, respectively. Moreover, unlike WR401, which is a natural toluate degrader, NK8 could not grow on $o^{-}, m$ - or $p$-toluate medium. The clustering in NK8 of the cbe genes with the catechol degradation genes further justifies the classification of NK8 CbeABC as a (chloro) benzoate dioxygenase.

\section{The CbeABC has a relaxed regiospecificity}

Strain NK8 (chloro)benzoate dioxygenase appears to lack absolute regioselectivity as revealed by the species of intermediates it generates from the asymmetrical substrates $2 \mathrm{CB}$ and $3 \mathrm{CB}$ (Fig. 2). 2CB binds with $\mathrm{NK} 8$ CbeABC either as $2 \mathrm{CB}$ or ' $6 \mathrm{CB}$ ', apparently with equal affinity. The subsequent 1-2 dioxygenation of $2 \mathrm{CB}$ gives rise to the unstable intermediate 2-chloro-3,5-cyclohexadiene-1,2-diol-1-carboxylic acid (2-chloro$\mathrm{DHB}$ ), which spontaneously loses $\mathrm{Cl}^{-}$to generate catechol. Dioxygenation of ' $6 \mathrm{CB}$ ' gives rise to 6-chloro- 
DHB, which upon dehydrogenation by $\mathrm{CbeD}$ is converted into 3CC. The preference of NK8 dioxygenase for $3 \mathrm{CB}$ that binds as ' $5 \mathrm{CB}$ ' (the $\mathrm{Cl}^{-}$substituent is distal to the dioxygenation point) rather than as $3 \mathrm{CB}$, as indicated by the production of greater amount of $4 \mathrm{CC}$ than 3CC from 3CB, likewise demonstrates the lack of absolute regioselectivity of the NK8 dioxygenase. Low regiospecificity was also reported for other 2CBoxidizing enzymes such as those of $P$. aeruginosa JB2 (Hickey \& Focht, 1990) and Pseudomonas sp. 3CBS (Sylvestre et al., 1989), which generate 3CC and catechol from 2CB. In contrast, dioxygenases with absolute regiospecificity, as exemplified by the $\mathrm{CbdABC}$ of $P$. cepacia 2CBS (Fetzner et al., 1989) and by the orthohalobenzoate 1,2-dioxygenase of $P$. aeruginosa 142 (Romanov \& Hausinger, 1994; Tsoi et al., 1999), yield only catechol from the dioxygenation of $2 \mathrm{CB}$.

\section{CB and 4CB are degraded via chlorocatechols in strain NK8}

The complete degradation of benzoate and chlorobenzoates by NK8 apparently proceeds via separate routes as outlined in Fig. 6. Catechol, the CbeABCDcatalysed oxidation intermediate product from benzoate and $2 \mathrm{CB}$, is likely to be converted by the ortho-cleavage pathway enzymes CatA, CatB and CatC, while the 3CC and $4 \mathrm{CC}$ generated from $3 \mathrm{CB}, 4 \mathrm{CB}$ and $2 \mathrm{CB}$ are processed via the modified ortho-cleavage pathway by the chlorocatechol-oxidizing enzymes. Substantiating this scheme are the following observations. NK8 mutants that are incapable of utilizing $3 \mathrm{CB}$ and $4 \mathrm{CB}$, but could grow on benzoate, arose spontaneously after repeated subculture in LB. The chlorocatechol degradation genes of NK8, which have been cloned from its large plasmid, were shown by Southern hybridization to be absent in the mutants (unpublished data). Complementation of one of the spontaneous NK8 mutants (plasmid ${ }^{-}, 3 \mathrm{CB}^{-}$and $4 \mathrm{CB}^{-}$) with either the Ralstonia eutropha NH9 chlorocatechol genes cbnRABCD in pEKC1 (Ogawa \& Miyashita, 1999) or the plasmidborne NK8 chlorocatechol genes enabled the mutant to grow on $3 \mathrm{CB}$ and $4 \mathrm{CB}$ (unpublished data). These observations indicate that the plasmid-encoded chlorocatechol catabolic genes of the modified ortho pathway are involved in the transformation of 3CC and 4CC. Also, cat A could take part in the transformation of 4CC to 3-chloro-cis, cis-muconate in NK8, as in other bacteria (Dorn \& Knackmuss, 1978; Kim et al., 1997; SauretIgnazi et al., 1996).

\section{The convergent organization of the cbe-cat gene cluster}

The organization of the cbe and cat genes in NK8 is unique when compared with the corresponding genes of other Proteobacteria. Mapping studies indicated that both benzoate 1,2-dioxygenase genes (ben) and catechol 1,2-dioxygenase genes (cat) are contiguous but seemingly exist as distinct units in both the $P$. putida and $P$. aeruginosa chromosomes (Houghton et al., 1995; Jeffrey et al., 1992; Zhang et al., 1993a, b). In the wellcharacterized Acinetobacter sp. ADP1, a close physical association between the ben and cat gene clusters is evident, but the gene clusters are still distinctly separate (Collier et al., 1998; Neidle et al., 1987). Although the cbe and cat genes are also clustered in NK8, there are significant differences between ADP1 and NK8 in terms of the organization of the corresponding genes in the cluster. While the benABCD (and benE) genes exist as a distinct operon in ADP1, cbeA (and probably $c b e B C D$ ) forms an operon with cat $A$ in NK8 (Fig. 1). While benE is downstream of and cotranscribed with ben $A B C D$ in ADP1, the corresponding gene $c b e E$ of NK8 is downstream of catC. In ADP1, the ben and cat genes have their own LysR-type regulatory genes, i.e. benM and cat $M$, respectively, catM regulating only the cat genes, while benM is able to regulate both ben and cat genes (Collier et al., 1998). In contrast, only the single LysRtype regulatory gene $c b e R$, which positively regulates the expression of $c a t A$ and $c b e A(B C D)$, and probably cat $B C$, is present in the $c b e-c a t$ gene cluster of NK8 (Fig. 1). These organizational features of the NK8 cat and ben gene clusters, i.e. reshuffling, intermingling and coregulation, might represent evolutionary events more recent than those that occurred in ADP1, P. aeruginosa or P. putida, in which the independently derived but metabolically related cat and ben gene clusters were brought physically close together by selection pressures (Harwood \& Parales, 1996). The close proximity of cat $A$ and cbeABCD, coupled with their co-expression, further substantiates the perceived importance of benzoate as a favoured substrate that is funnelled into the catechol branch of the $\beta$-ketoadipate pathway (Harwood \& Parales, 1996).

\section{(Chloro)benzoates are inducers of the transcriptional activation of the catA promoter}

The transcriptional fusion study in P. putida PRS4020 showed that the transcription of $c a t A$ and $c b e A(B C D)$ is regulated by CbeR. Results of the $\beta$-galactosidase assay of NBALZ, the cbeA: : lacZ-Km ${ }^{\mathrm{r}}$ disruptant strain (Fig. 5 ), indicate that cbe $A$ is induced by $3 \mathrm{CB}, 4 \mathrm{CB}$, benzoate and cis,cis-muconate. In the well studied benzoatedegrading bacterium Acinetobacter sp. ADP1, cis, cismuconate converted from catechol induces the expression of the benzoate dioxygenase (ben) genes and catechol dioxygenase (cat) genes (Collier et al., 1998). In P. putida, cis, cis-muconate from catechol also activates the cat genes (Parsek et al., 1992). The amino acid residues in the putative binding region conserved among cis, cis-muconate-responsive regulatory proteins are also conserved in CbeR (from Ile-98 to Glu-152; data not shown). Although the possibility that the degradation product of cis, cis-muconate acts as an effector cannot be excluded, it is probable that cis,cis-muconate binds to CbeR and then activates the coupled transcription of cat $A$ and $c b e A$. The observed increase in $\beta$-galactosidase activity with catechol could be attributed to the cis, cismuconate rapidly generated from catechol by CatA. 
Quantitative HPLC analysis showed that benzoate and chlorobenzoates are not degraded by NBALZ. Therefore, the inducers of $c b e A$ expression observed in lacZ assay of NBALZ are benzoate and chlorobenzoates themselves. BenM of Acinetobacter sp. ADP1 also responds to benzoate (Collier et al., 1998). However, the overall identity of CbeR with BenM (45\%) is lower than that with CatR of P. putida RBS2000 $(50 \%)$ and RB1 $(48 \%)$, which respond to cis,cis-chloromuconate (Houghton et al., 1995 ; Parsek et al., 1992). NK8 CbeR appears to be the first example of a LysR-type regulator involved in the degradation of (chloro)benzoate that recognizes chlorobenzoates as inducers. The difference among the three monochlorobenzoate isomers in their ability to induce cbeA expression is obvious, $3 \mathrm{CB}$ and 4CB being as effective as benzoate and cis,cis-muconate, while $2 \mathrm{CB}$ is not an inducer (Fig. 5). The difference in their ability to support the growth of NK8 is also evident. NK8 grows well on $3 \mathrm{CB}$ and $4 \mathrm{CB}$ but does not grow on $2 \mathrm{CB}$, notwithstanding the significant transformation by NK8 cell lysate of these three chlorobenzoate isomers (Table 2). The absence of growth of NK8 on 2CB may be due to the inability of CbeR to recognize $2 \mathrm{CB}$ as an effector. The induction of oxidative genes, in addition to the substrate specificity of the encoded enzymes, can be a bottleneck in the degradation of chlorobenzoate. Apparently, regulator recognition of effectors is essential in determining the substrate specificity of chlorobenzoate-degrading bacteria.

\section{ACKNOWLEDGEMENTS}

The authors are grateful to Dr W. Lotz and Dr S. Heidingsfelder (Friedrich-Alexander Universität, Erlangen, Germany) for the kind gift of pKOK6.1. This work was supported by a grant from the Program for the Promotion of Basic Research Activities for Innovative Biosciences (PROBRAIN).

\section{REFERENCES}

Aldrich, T. L., Frantz, B., Gill, J. F., Kilbane, J. J. \& Chakrabarty, A. M. (1987). Cloning and complete nucleotide sequence determination of the $c a t B$ gene encoding cis, cis-muconate lactonizing enzyme. Gene 52, 185-195.

Ausubel, F. M., Brent, R., Kingston, R. E., Moore, D. D., Seidman, J. G., Smith, J. A. \& Struhl, K. (1987). Current Protocols in Molecular Biology. New York: Wiley.

Batie, C. J., Ballou, D. P. \& Correl, C. J. (1992). Phthalate dioxygenase reductase and related flavin-iron-sulfur-containing electron transferases. In Chemistry and Biochemistry of Flavoenzyme, pp. 544-554. Edited by F. Müller. Boca Raton, FL: CRC Press.

Blondelet-Rouault, M., Weiser, J., Lebrihi, A., Branny, P. \& Perdonet, J. (1997). Antibiotic resistance gene cassettes derived from the $\Omega$ interposon for use in E. coli and Streptomyces. Gene 190, 315-317.

Bundy, B. M., Campbell, A. L. \& Neidle, E. L. (1998). Similarities between the ant $A B C$-encoded anthranilate dioxygenase and the ben $A B C$-encoded benzoate dioxygenase of Acinetobacter sp. strain ADP1. J Bacteriol 180, 4466-4474.

Collier, L. S., Gaines, G. L. \& Neidle, E. L. (1998). Regulation of benzoate degradation in Acinetobacter calcoaceticus sp. strain
ADP1 by BenM, a LysR-type transcriptional activator. J Bacteriol 180, 2493-2501.

Danganan, C. E., Ye, R. W., Daubaras, D. L., Xun, L. \& Chakrabarty, A. M. (1994). Nucleotide sequence and functional analysis of the genes encoding 2,4,5-trichlorophenoxyacetic acid oxygenase in Pseudomonas cepacia AC1100. Appl Environ Microbiol 11, 4100-4106.

Daubaras, D. L. \& Chakrabarty, A. M. (1992). The environment, microbes and bioremediation: microbial activities modulated by the environment. Biodegradation 3, 125-135.

Davison, J., Heusterspreute, M., Chavelier, N., Ha-Thi, V. \& Brunel, F. (1987). Vectors with restriction-site banks. V.pJRD215, a wide-host-range cosmid vector with multiple cloning sites. Gene 51, 275-280.

Dorn, E. \& Knackmuss, H. J. (1978). Chemical structure and biodegradability of halogenated aromatic compounds: substituent effects on 1,2-dioxygenation of catechol. Biochem $J$ 174, 85-94.

Farinha, M. A. \& Kropinski, A. M. (1990). Construction of broadhost-range plasmid vectors for easy visible selection and analysis of promoters. J Bacteriol 172, 3496-3499.

Fetzner, S., Müller, R. \& Lingens, F. (1989). Degradation of 2chlorobenzoate by Pseudomonas cepacia 2CBS. Biol Chem Hoppe-Seyler 370, 1173-1182.

Fetzner, S., Müller, R. \& Lingens, F. (1992). Purification and some properties of 2-halobenzoate 1,2-dioxygenase, a two-component enzyme system from Pseudomonas cepacia 2CBS. J Bacteriol 174, 279-290.

Focht, D. D. (1996). Biodegradation of chlorobenzoates. In Molecular Biology of Pseudomonas, pp. 71-80. Edited by T. Nakazawa, K. Furukawa, D. Haas \& S. Silver. Washington, DC: American Society for Microbiology.

Franklin, F. C. H. (1985). Broad host range cloning vectors for gram negative bacteria. In DNA Cloning, pp. 165-184. Edited by D. M. Glover. Oxford: IRL Press.

Frantz, B. \& Chakrabarty, A. M. (1987). Organization and nucleotide sequence determination of a gene cluster involved in 3chlorocatechol degradation. Proc Natl Acad Sci USA 84, 4460-4464.

Haak, B., Fetzner, S. \& Lingens, F. (1995). Cloning, nucleotide sequence, and expression of the plasmid-encoded genes for the two-component 2-halobenzoate 1,2-dioxygenase from Pseudomonas cepacia 2CBS. J Bacteriol 177, 667-675.

Hanahan, D. (1985). Techniques for transformation of E. coli. In DNA Cloning, pp. 109-135. Edited by D. M. Glover. Oxford: IRL Press.

Harayama, S., Rekik, M., Bairoch, A., Neidle, E. L. \& Ornston, L. N. (1991). Potential DNA slippage structures acquired during evolutionary divergence of Acinetobacter calcoaceticus chromosomal benABC and Pseudomonas putida TOL pWW0 plasmid $x y l X Y Z$ genes, encoding benzoate dioxygenases. J Bacteriol 173 , 7540-7548.

Harwood, C. S. \& Parales, R. E. (1996). The $\beta$-ketoadipate pathway and the biology of self-identity. Annu Rev Microbiol 50, 553-590.

Hickey, W. J. \& Focht, D. D. (1990). Degradation of mono-, di-, and tri-halogenated benzoic acids by Pseudomonas aeruginosa JB2. Appl Environ Microbiol 56, 3842-3850.

Houghton, J. E., Brown, T. M., Appel, A. J., Hughes, E. J. \& Ornston, L. N. (1995). Discontinuities in the evolution of Pseudomonas putida cat genes. J Bacteriol 177, 401-412.

Jeffrey, W. H., Cuskey, S. M., Chapman, P. J., Resnik, S. \& Olsen, R. H. (1992). Characterization of Pseudomonas putida mutants 
unable to catabolize benzoate: cloning and characterization of Pseudomonas genes involved in benzoate catabolism and isolation of chromosomal DNA fragments able to substitute for $x y l S$ activation of TOL lower-pathway promoter. J Bacteriol 174, 4986-4996.

Kim, S. I., Leem, S.-H., Choi, J.-S., Chung, Y. H., Kim, S., Park, Y.-M., Park, Y. K., Lee, Y. N. \& Ha, K.-S. (1997). Cloning and characterization of two catA genes in Acinetobacter lwoffii K24. $J$ Bacteriol 179, 5226-5231.

Kokotek, W. \& Lotz, W. (1989). Construction of a lacZkanamycin-resistance cassette, useful for site-directed mutagenesis and as a promoter probe. Gene 84, 467-471.

de Lorenzo, V. \& Timmis, K. N. (1994). Analysis and construction of stable phenotype in gram-negative bacteria with Tn5- and Tn10-derived minitransposons. Methods Enzymol 235, 387-405.

McFall, S. M., Chugani, S. A. \& Chakrabarty, A. M. (1998). Transcriptional activation of the catechol and chlorocatechol operons: variations on a theme. Gene 223, 257-267.

van der Meer, J. R., de Vos, W. M., Harayama, S. \& Zehnder, A. J. B. (1992). Molecular mechanism of genetic adaptation to xenobiotic compounds. Microbiol Rev 56, 677-694.

Miller, J. H. (1972). Experiments in Molecular Genetics. Cold Spring Harbor, NY: Cold Spring Harbor Laboratory.

Murakami, S., Takashima, A., Takemoto, J., Takenaka, S., Shinke, R. \& Aoki, K. (1999). Cloning and sequence analysis of two catechol-degrading gene clusters from the aniline-assimilating bacterium Frateuria sp. ANA-18. Gene 226, 189-198.

Nakatsu, C. H. \& Wyndham, R. C. (1993). Cloning and expression of the transposable chlorobenzoate 3,4-dioxygenase genes of Alcaligenes sp. strain BR60. Appl Environ Microbiol 59, 3625-3633.

Nakatsu, C. H., Straus, N. A. \& Wyndham, R. C. (1995). The nucleotide sequence of the Tn5271 3-chlorobenzoate 3,4dioxygenase genes $(c b a A B)$ unites the class IA oxygenases in a single lineage. Microbiology 141, 485-495.

Nakatsu, C. H., Providenti, M. \& Wyndham, R. C. (1997). The cisdiol dehydrogenase $c b a C$ gene of $\operatorname{Tn} 5271$ is required for growth on 3-chlorobenzoate but not on 3,4-dichlorobenzoate. Gene 196, 209-218.

Neidle, E. L., Shapiro, M. \& Ornston, L. N. (1987). Cloning and expression in E. coli of Acinetobacter calcoaceticus genes for benzoate degradation. J Bacteriol 169, 5496-5503.

Neidle, E. L., Hartnett, C., Ornston, L. N., Bairoch, A., Rekik, M. \& Harayama, S. (1991). Nucleotide sequences of the Acinetobacter calcoaceticus ben $A B C$ genes for benzoate 1,2-dioxygenase reveal evolutionary relationship among multicomponent oxygenases. $J$ Bacteriol 173, 5385-5395.

Ogawa, N. \& Miyashita, K. (1995). Recombination of a 3chlorobenzoate catabolic plasmid from Alcaligenes eutrophus NH9 mediated by direct repeat elements. Appl Environ Microbiol 61, 3788-3795.

Ogawa, N. \& Miyashita, K. (1999). The chlorocatechol-catabolic transposon Tn5707 of Alcaligenes eutrophus NH9, carrying a gene cluster highly homologous to that in the 1,2,4trichlorobenzene-degrading bacterium Pseudomonas sp. strain P51, confers the ability to grow on 3-chlorobenzoate. Appl Environ Microbiol 65, 724-731.

Parales, R. E. \& Harwood, C. S. (1993). Regulation of the pcalJ genes for aromatic acid degradation in Pseudomonas putida. J Bacteriol 175, 5829-5838.

Parsek, M. R., Shinabarger, D. L., Rothmel, R. K. \& Chakrabarty, A. M. (1992). Roles of CatR and cis, cis-muconate in activation of the cat $B C$ operon, which is involved in benzoate degradation in Pseudomonas putida. J Bacteriol 174, 798-806.

Reineke, W. (1998). Development of hybrid strains for the mineralization of chloroaromatics by patchwork assembly. Annu Rev Microbiol 52, 287-331.

Romanov, V. \& Hausinger, R. P. (1994). Pseudomonas aeruginosa 142 uses a three-component ortho-halobenzoate 1,2-dioxygenase for metabolism of 2,4-dichloro- and 2-chlorobenzoate. J Bacteriol 176, 3368-3374.

Romero-Arroyo, C. E., Schell, M. A., Gaines, G. L. \& Neidle, E. L. (1995). catM encodes a LysR-type transcriptional activator regulating catechol degradation in Acinetobacter calcoaceticus. J Bacteriol 177, 5891-5898.

Rothmel, R. K., Aldrich, T. L., Houghton, J. E., Coco, W. M., Ornston, L. N. \& Chakrabarty, A. M. (1990). Nucleotide sequencing and characterization of Pseudomonas putida catR: a positive regulator of the catBC operon is a member of the LysR family. J Bacteriol 172, 922-931.

Sambrook, J., Fritsch, E. F. \& Maniatis, T. (1989). Molecular Cloning: a Laboratory Manual, 2nd edn. Cold Spring Harbor, NY : Cold Spring Harbor Laboratory.

Sauret-Ignazi, G., Gagnon, J., Beguin, C., Barrell, M., Marcowicz, Y., Pelmont, J. \& Toussaint, A. (1996). Characterization of a chromosomally encoded catechol 1,2-dioxygenase (EC 1.13.11.1) from Alcaligenes eutrophus $\mathrm{CH} 34$. Arch Microbiol 166, 42-50.

Schweizer, H.P. (1992). Allelic exchange in Pseudomonas aeruginosa using novel ColE1-type vectors and a family of cassettes containing a portable oriT and the counter-selectable Bacillus subtilis sacB marker. Mol Microbiol 6, 1195-1204.

Simon, R., Priefer, U. \& Pühler, A. (1983). A broad host-range mobilization system for in vitro genetic engineering: transposon mutagenesis in gram-negative bacteria. Bio/Technology 1, 784-791.

Smith, M., Jesse, J., Landers, T. \& Jordan, J. (1990). High efficiency bacterial electroporation: $1 \times 10^{10}$ E. coli transformants/ $\mu \mathrm{g}$. Focus 12, 38-40.

Sylvestre, M., Mailhiot, K., Ahmad, D. \& Masse, R. (1989). Isolation and preliminary characterization of a 2-chlorobenzoate degrading Pseudomonas. Can J Microbiol 35, 439-443.

Tsoi, T. V., Plotnikova, E. G., Cole, J. R., Guerin, W. F., Bagdasarian, M. \& Tiedje, J. M. (1999). Cloning, expression, and nucleotide sequence of the Pseudomonas aeruginosa $142 \mathrm{obb}$ genes coding for oxygenolytic ortho dehalogenation of halobenzoates. Appl Environ Microbiol 65, 2151-2162.

Unterman, R. (1996). A history of PCB biodegradation. In Bioremediation: Principles and Applications, pp. 209-253. Edited by R. L. Crawford \& D. L. Crawford. Cambridge: Cambridge University Press.

Vieira, J. \& Messing, J. (1987). Production of single-stranded plasmid DNA. Methods Enzymol 153, 3-11.

Zhang, C., Huang, M. \& Holloway, B. W. (1993a). Mapping of ben, ant, and cat genes of Pseudomonas aeruginosa and evolutionary relationship of the ben region of $P$. aeruginosa and $P$. putida. FEMS Microbiol Lett 108, 303-310.

Zhang, C., Huang, M. \& Holloway, B. W. (1993b). Mapping of ben genes of Pseudomonas aeruginosa. FEMS Microbiol Lett 112, $255-259$.

Received 12 April 2000; revised 7 September 2000; accepted 14 September 2000. 